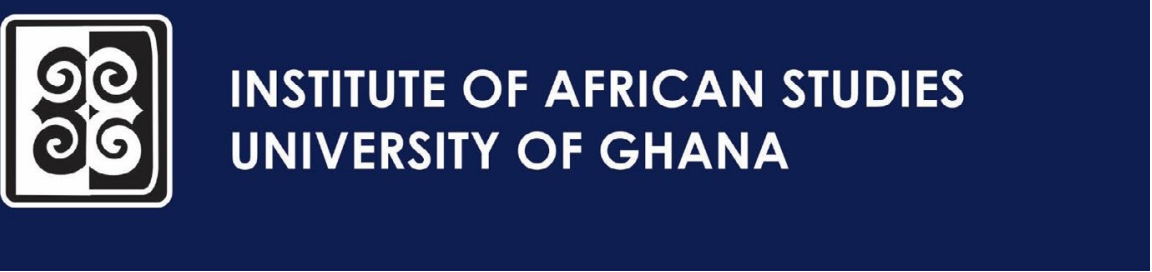

Contemporary Journal of African Studies 2020; 7 (1): 1-16

https://dx.doi.org/10.4314/contjas.v7i1.1

ISSN 2343-6530

(C) 2020 The Author(s)

Open Access article distributed under the terms of the

Creative Commons License [CC BY-NC-ND 4.0]

http://creativecommons.org/licenses/by-nc-nd/4.0

\section{Mainstreaming the Discourse on Restitution and Repatriation within African History, Heritage Studies and Political Science}

\section{Wazi Apoh $^{1} \&$ Andreas Mehler ${ }^{2}$}

${ }^{1}$ Associate Professor, Department of Archaeology and Heritage Studies, University of Ghana,

Authoremail:wapoh@ug.edu.gh

${ }^{2}$ Professor, Department of Political Science, Freiburg University

Author email: andreas.mehler@abi.uni-freiburg.de

\section{Abstract}

The recent upsurge of interest in restitution and repatriation debates by practitioners and scholars might offer appropriate chances for true interdisciplinary research. Not only should historical, anthropological and legal studies take part in such a conversation, but also, political science, archaeology and heritage studies. Resolutely and systematically giving voice to both African stakeholders and African researchers is an imperative. In this introduction, the fresh start of a rich debate is traced, providing the framework for processing and understanding current debates and practices of restitution. Essential and neglected questions are formulated. Detected voids call for the mainstreaming of a new discourse on restitution and repatriation to play a pivotal role in the epistemology of these allied disciplines and training.

Keywords: mainstreaming, restitution, repatriation debates, African voices, interdisciplinary research. 


\title{
Mainstreaming the Discourse on Restitution and Repatriation within African History, Heritage Studies and Political Science
}

\author{
Wazi Apoh and Andreas Mehler
}

\begin{abstract}
The recent upsurge of interest in restitution and repatriation debates by practitioners and scholars might offer appropriate chances for true interdisciplinary research. Not only should historical, anthropological and legal studies take part in such a conversation, but also, political science, archaeology and heritage studies. Resolutely and systematically giving voice to both African stakeholders and African researchers is an imperative. In this introduction, the fresh start of a rich debate is traced, providing the framework for processing and understanding current debates and practices of restitution. Essential and neglected questions are formulated. Detected voids call for the mainstreaming of a new discourse on restitution and repatriation to play a pivotal role in the epistemology of these allied disciplines and training.
\end{abstract}

Key words: mainstreaming restitution, repatriation debates, African voices, interdisciplinary research.

\section{https://dx.doi.org/10.3414/contjas.v7i1.1}

Prof. Wazi Apoh (wapoh@ug.edu.gh) is Associate Professor of Archaeology and Heritage Studies at the University of Ghana. His specialty is in the fields of African archaeology, cultural heritage management, contract/salvage archaeology, forensic archaeology, the archaeology of German missionization and colonization of 'Togoland' and the archaeology of slavery in the Southern Volta of Ghana. He was Head of Department of Archaeology and Heritage Studies, University of Ghana between 2016 and 2018 and two time President of the West African Archaeological Association (WAAA) between 2015 and 2019. He is the author of Revelations of Domination and Resilience: Unearthing the Buried Past of the Akpinis, Akans, Germans and British at Kpando, Ghana. Sub-Saharan Publishers, Accra (2019) and Concise Anthropology: The Five-Field Approach (2010). His co-edited books include "Germany and Its West African Colonies: "Excavations" of German Colonialism in Post-Colonial Times.' (With Professor B. Lundt; 2013) and also 'Current Perspectives on the Archaeology of Ghana,' (with Professor J. Anquandah and Professor B. Kankpeyeng; 2014).

Prof. Andreas Mehler (andreas.mehler@abi.uni-freiburg.de) is Director of the Arnold Bergstraesser Institute and Professor of Political Science at Freiburg University, Germany. He was Senior Researcher at the Conflict Prevention Network in Berlin between 2001 and 2002 and Director of the GIGA Institute of African Affairs in Hamburg between 2002 and 2015. He is the president of the executive council of the Merian Institute for Advanced Studies in Africa (MIASA). Together with Henning Melber, he has co-edited the peerreviewed and fully open-access academic journal Africa Spectrum from 2009 to 2018 and is co-editor of the yearly Africa Yearbook. Mehler has published extensively on conflict and security, state and statehood, power sharing, French Africa policy and democratisation in Africa south of the Sahara. 


\section{Résumé}

L'émergence récente d' un nouvel intérêt dans les débats sur la restitution et sur le rapatriement d' objets d'art africains exprimés par les praticiens et par les chercheurs pourrait se traduire en une ouverture vers une véritable recherche interdisciplinaire. La science politique, l'archéologie ainsi que les études de patrimoine, tout comme l' histoire, l' anthropologie et le droit, doivent participer à cet échange interdisciplinaire. Il est impératif de donner - d' une manière résolue et systématique - la voix aux acteurs et chercheurs africains. Cette introduction retrace le nouveau départ d' un débat riche fournissant le cadre pour le traitement et pour l' appréciation des débats et des pratiques courants relatifs à la restitution. Des questions essentielles et négligées sont d'abord formulées. Les lacunes détectées appellent à la promotion d'un nouveau discours sur le rapatriement et la restitution, ce qui jouerait un rôle central dans l'épistémologie desdites disciplines et formations connexes.

Mots-clés: la restitution comme courant principal, débats sur le rapatriement, voix africaines, recherche interdisciplinaire.

\section{Introduction: Restitution and Repatriation as the Beginning and End Products of a Process?}

The missionizing and colonizing missions of the French, British, Scandinavians, Dutch and Germans ${ }^{1}$ with or without the assistance of local agents were not without resounding repercussions. One of the driving forces of colonialism was the extraction of important material resources like rubber and minerals through the exploitation of African labour forces on plantations and mines. In addition, "cultural resources" were targeted. Museums all around Europe were looking for art objects from Africa and at times communicated lists of objects to military expeditions with the purpose of getting the "right" things to end up in their collections. Indeed, the continent witnessed aggressive acquisitions that included looted objects from shrines, palaces, and public spaces of some African societies which were then taken to various homelands in Europe and America over time (Leijten, 2015). This looting and collection of African antiquities characterized the periods of the slave raids and trade in humans from the $15^{\text {th }}$ century until the trade's abrogation in the twentieth century (Van Dantzig, 1980). The looting of most African objects also occurred during the later period of missionization from the early $19^{\text {th }}$ century, when most shrines and their objects in Africa were demonized. In the process, the sacred objects were either destroyed as being anti-Christian or salvaged, packaged and shipped abroad by missionaries and European merchants (Leijten, 2015). The period of formal colonization of African societies after the Berlin Conference of 1884-85 also saw sustained attempts and practices of colonial looting of such African artworks (Nkrumah, 1962). Most of these objects were later willed, sold or gifted to museums in Europe while others ended up as commodities on the global art market, being auctioned and exchanged, at times ending up in private galleries.

\footnotetext{
${ }^{1}$ These were the major European players involved in the territory that would become modern day Ghana. Portuguese, Spanish, Italian or Belgian involvement was important in other parts of Africa.
} 
The demands and pleas for repatriation and restitution of these looted and illegally acquired African cultural objects in European museums back to their African source communities have gained currency since the 1970s (M'Bow, 2009, Van Beurden 2015). Strangely, the vivid discussions of the late 1970s and early 1980s ended rather abruptly in the mid-1980s and only individual claims for the return of specific objects were sporadically voiced. ${ }^{2}$ It was in the second part of the 2010s that a new wave of discussions unfolded. French President Emmanuel Macron's 2017 speech given in Ouagadougou ${ }^{3}$ and the subsequent publication of the commissioned Sarr and Savoy report (Sarr \& Savoy, 2018) were landmark events. While some voices questioned the motives of Macron ${ }^{4}$, one could hardly deny that he initiated the start of a multifaceted debate which also clearly put aspects of rightful claims (and not a favour by benevolent European decisionmakers) to the fore, inscribed in the word 'restitution' (see recent publications focussing on controversies such as Hersak, 2019; Murphy and Tillier, 2019; and Thiemeyer 2019). On the one hand, one could look at the current debate as the penultimate step in a long decolonisation process that will culminate in African communities being reunited with their long lost and looted antiquities. On the other hand, the first wave of repatriations being currently witnessed could be assessed as the beginning of a sincere exchange between Africa and Europe on different levels - societal, diplomatic, and academic - which, however, is still in its infancy. The on-going public discourses on the return of such objects based on active requests, avant-garde activism, scholarly debates, political (in)decision vis a vis the entrenched but evolving perspective of the foreign gate keepers of African heritage remains, are increasingly being defined and redefined at various uncoordinated fora, conferences, workshops and talk shops. It is however time to relate the different strands of the discussion into a coherent action that would in the end have tangible results or ignite similar fora on the African continent. In view of this, we regard the collection of contributions in this volume as a modest attempt to achieve this.

Yet, the question remains: how well are these debates informed by historical and contextual information? More so, how well has this discourse been critically packaged and theorized beyond its practical and rhetorical dimensions for the capacity building of heritage enthusiasts/activists and for the consumption of the general public? Similarly, how well are African studies, history, archaeology, anthropology, heritage studies and political science curricula positioned to engage with and provide enlightenment on the ensuing debates on restitution? From our perspective, they still fall short of expectations. Detected voids call for the mainstreaming of a new discourse on restitution and repatriation to play a pivotal

\footnotetext{
2 Bénédicte Savoy currently researches this period and gave a revealing talk at Freiburg University on 23 January 2020, podcast available at https://videoportal.uni-freiburg.de/video/Benedicte-SavoyTU-Berlin-Zurueck-in-die-Zukunft-Die-Restitution-afrikanischer-Kulturgueter-aus-historischerSicht/01e10965d8b20061903cd53d6c6198d7 (accessed 4 February 2020).

3 https://www.elysee.fr/emmanuel-macron/2017/11/28/discours-demmanuel-macron-a-luniversite-deouagadougou (accessed 4 February 2020).

4 "Most ferociously formulated by Achille Mbembe, claiming that Europe would not have the right to restitute African objects as it would close too easily a difficult chapter of history." See https:// www.deutschlandfunk.de/historiker-mbembe-zum-postkolonialismus-europa-hat-kein.691. de.html?dram:article id=430060 (accessed 4 February 2020).
} 
role in the epistemology of these allied disciplines and training. ${ }^{5}$ The case studies examined here also substantiate novel understandings and evolving perspectives and unending processes associated with this subject matter.

\section{Mainstreaming the Discourse in Political Science}

Political science, put crudely, is mostly interested in power relations and state institutions. Power dimensions were obvious in the way African cultural objects were acquired, either by force, trickery or through the use of money and persuasion. It is also easy to establish evidence of power asymmetries in a simple gain versus loss perspective. Some African traders and sellers may have gained some rewards while some European collectors may have lost capital with some even losing their lives during their adventures. But the overall picture of the distribution of winners and losers by continent is clear: a good part of Africa's treasures have ended up in Europe - a fact that is today perceived widely as a loss to African societies.

Among prominent institutions involved in these acquisitions are museums in Europe that had assigned themselves some domestic political functions at the turn of the $19^{\text {th }}$ to the $20^{\text {th }}$ centuries. These could be assessed in terms of identity production ("we" and "them") mostly by affirming some form of European (in fact German, French, and British) superiority. While admittedly museums have a whole array of other functions, the following reflections deliberately focus on power and power asymmetries. From a political science point of view, today's salient issue of restitution of colonially acquired or looted art objects raises a number of aspects. Unfortunately, most of them are only marginally or indirectly addressed in the current restitution debate, which is dominated by legal, anthropological, historical and didactical perspectives. Key aspects that need to be theorized and deliberated on in theory and practice include, among others:

- representation of group interests and legitimacy in negotiation processes

- empowerment and participation of communities of origin

- management of conflicting claims

- memory politics ("Vergangenheitspolitik") associated with restitution and exhibition policies - both in (African) countries of origin and (European) countries of current sojourn of objects

- multi-level governance dimensions from a local via national, sub-regional and regional to an international/global level

Representation of Group Interests and Legitimacy in Negotiation Processes: Negotiations often involve two (or more) parties. Usually, communities of origin of disputed objects or objects being requested for repatriation are represented by a small number of spokespersons. One of the obvious problems in narrowing down the number of negotiators is to preserve a fair level of representation on behalf of a given community. The question, however, is who selects representatives for such negotiations and what kind of local or cultural framework informs such choices? Is a government spokesperson, with a potentially diverging local background, capable of speaking on behalf of the source community? How are rhetorically strong and well-connected personalities in institutions who claim to be from the 'right' origin,

\footnotetext{
${ }^{5}$ For a similar argument see Mirjam Brusius, Hand in Hand, in Süddeutsche Zeitung, 26 January 2020, https://www.sueddeutsche.de/kultur/wissenschaft-und-museen-dekolonisieren-hand-inhand-1.4772201 (accessed 4 February 2020). 
different from self-acclaimed 'cultural entrepreneurs'? There can be a bone of contention when the positionality or identity of such people is questioned by their own communities. Superficial consultation of hand-picked traditional authorities might be far from what a decent participatory approach should look like. In short - the representation and perception of the legitimacy of key actors are highly critical. In a way, a substantial representation of a community' s interest may be better achieved by disinterested but equally concerned technocrats. However, their existence cannot be taken for granted everywhere. These are not abstract challenges in today's restitution processes and the outcome of a negotiation process may become contested if issues of representation are not explicitly addressed from the local and governmental levels. The remaining big question then concerns how we can encourage cultural and political exchange at a level playing field?

Empowerment and Participation of Communities of Origin: Some objects may have been owned by individuals whose descendants may or may not have claims on them. In the recent prominent case of the restitution of Nama leader Henrik Witbooi' $s$ Bible and whip to Namibia, it is clear that these were his personal possessions that were taken as booty during a raid by German troops (see Koessler, 2019). Knowledge about the existence of such objects and their genealogy is therefore a key pre-condition in comparable cases. The political aspect of this particular act of restitution has to do with the exceptional role this individual played at the turn of the $19^{\text {th }}$ to the $20^{\text {th }}$ centuries within - again - a particular political space. One of the big challenges of restitution is awareness raising within and for such groups on the existence of relevant objects taken from their communities and ancestors of which they have potential entitlements to get back. It is, more or less, evident that only a handful of restitutions do occur without a claim or request. On the other hand, it could also well be that some objects are so poisonous in literal or symbolic respects ${ }^{6}$ that nobody wants them back. It is therefore also an issue of participation to find out which objects are perceived as problematic. Empowerment, finally, would also entail some sort of capacity-building in terms of formulating successful claims, seeking support from African governments and finding the appropriate owners and avenue to access decision-makers in former colonizing countries.

Management of Conflicting Claims: In most prominent cases, a royal house will request or reclaim objects. Chances are that such objects and their acquisition will be or are well documented in their oral accounts. One source of (even potentially violent) conflict in some circumstances is the incidence of competing claims to a royal throne by different lineages in a source community. In the instance where an object is returned to one of such a community, the process of such a restitution could be perceived, from one point of view, as "hijacked" by one side. Notably, the possession of an object associated with royalty may become an instrument in a throne claim game. This is the least comfortable situation for those willing to engage in restitution. This is the reason why it is essential to know about the existence of competing claims in the first place and to invest in historical analysis

\footnotetext{
${ }^{6}$ We refer to a talk by Jeremy Sylvester at the 2018 VAD conference in Leipzig where he made comments both on objects in German museums full of pesticides that can only be kept under glass AND on objects reminding local people of their pagan past while they now prefer to be regarded as Christians. In both cases restitution might do more harm than good.
} 
where necessary. Engaging in compromises could permit conflicting parties to view restituted objects as part of a joint or shared heritage.

Memory Politics Associated with Restitution and Exhibition Policies: One prominent angle of consideration, especially for museums, in relation to restitution is "Vergangenheitspolitik" (meaning memory politics in German discourse). The specific German take with regard to the problematic parts of their history is often termed "Vergangenheitsbewältigung" in German. It literally means the management of a problematic part of history, which was more or less exclusively centered on the Nazi period. Calls to include the colonial past in this memory politics are legion, but only recently gaining prominence (Garsha, 2019). Both the problematic and the heroic sides of history can be highlighted by museums. Collections can be inclusive or exclusive by what they show and how they do it. This is obviously true for national museums existing in many African countries. A quite positive prospect would be that restituting symbolically loaded objects from "underrepresented" localities, and putting them in national museums, could lead to greater inclusivity.

Problems, however, persist. A national museum may be compelled to show what a segment of the population may want to see exhibited closer to their origin such as in a local museum. One of the most contested aspects of the return of the Witbooi Bible and whip to Namibia was the concern (by the Witbooi family) that those objects would be "abused" by the government of Namibia to ( $\mathrm{re}^{-}$) write a convenient history of resistance and glory of the Namibian state. They were also concerned that this has the potency of glossing over the non-existence of this state at the time of dispossession, important conflicts between local communities as well as the current feelings of marginalization of the Nama community. Koeßler (2019: 8) speaks of the competence of subnational groups "to autonomously address, well beyond and independent of governmental policy, the anti-colonial resistance of their ancestors, their sacrifice and their suffering."

One way of offering a differentiated history is to shape exhibitions by their accompanying texts or to simultaneously offer multiple interpretations. Presenting history in textbooks might be more influential, but museums and exhibitions can be instrumental in directly shaping the politics of history. This is equally true for the documentation of the various acts on restitution in European museums. These offer a chance to rewrite history, potentially more so on the problematic side of colonialism. Some precious objects displayed prominently in European museums for many decades were not acquired from a willing seller. Documenting their return at the same spot where they were previously exhibited offers a chance for appropriate memory politics. It is also in connection with the above that serious and concerted efforts that are supported by adequate funding needs to be applied in provenance research. Germany, for example, has identified this as a critical area of restitution process and has not only embedded it in the policy framework, the German Museums Association's Guidelines on Dealing with Collections from Colonial Contexts, but is providing funding at different levels. Provenance research, however, must in itself critique the way some of the information on the objects were conceived and written. As in co-curatorship advocated by a number of museums today, provenance research needs to bring together scholars from the source countries with those from the countries holding the collections so that truly informed research benefitting from shared knowledge can be rigorously produced. 
In absence of this co-researching, even well-meaning exercises of provenance investigation could suffer from projecting or repeating early collectors' biased perspectives and points of view.

Multi-leve/ governance: We have argued so far that restitution involves elements of power politics, creating winners and losers. This can be observed on a local and a national level. Therefore, it is not the most negligible part in the restitution practice to think about decentralized arenas or, more constructively, about a constant exchange from the local to the national level and rotating exhibitions. One particular problem, however, is that most of today's African states have colonial boundaries which cut through living spaces of pre-existing communities. This raises the issue of competence when it comes to restituting objects predating colonization which are associated with, for example, Ewe (Ghana/Togo) or Fang (Gabon/Equatorial-Guinea/Cameroon) history. If African governments negotiate for a return of such objects where would they end up? Trans-border communities would have to be taken care of - not only when it comes to restitution issues - by sub-regional organizations or specialized bodies within them, but this is a challenge. Not all of Africa's sub-regional organizations are similarly functional, so this calls for the African Union to also play roles in such issues.

Indirectly, the restitution debate could therefore give an impulse to multilevel governance in Africa and make some layers of governance more important to the lives of African citizens. It is not as if this problem would exempt Europe. Actually, the European arts market permitted trade of African cultural objects quite freely until recently. Even though the objects are today scattered all over the European continent, and museums and collections may have moral obligations to find an appropriate policy individually, it is clear that a collective European responsibility in colonization should be established. One may therefore ask for European legislation which should entail a much more homogeneous answer by the museums in all EU member states. However, till now restitution initiatives - both in Europe and Africa - are mostly of a national character. Interestingly, in the prominent case of "the Bible and the whip", both the government of the federal state of Baden-Württemberg, the city council of Stuttgart and the authorities of the local Lindenmuseum had to cooperate in order to make restitution possible.

The Namibian case is illustrative of many facets of the aforementioned political aspects of restitution. It was also a painful process over many years and not all its associated problems have been solved. Even more, it would be dramatic to lose out on the lessons of such a process. This all leads to a plea for a "best practice" approach that should allow for corrections and modifications to be made according to changing contexts and new knowledge. Some form of institutionalization of restitution processes might be needed. These can include: a) a routinized search for those who have claims, b) a phase in which potentially marginalized groups can be informed or empowered, c) an explicit mandate to those who speak on behalf of a group, $d$ ) identification of competing claims and care about "losers" in such processes, e) search for an appropriate exhibition policy accompanied by upholding circumspect, and more importantly f) ensuring appropriate forms of memory politics that would not turn the history of local communities into mere building blocks of a heroic national history. It would also be important to set standards on a supranational level, in Africa and in Europe. Such an approach could recognize 
that we are facing a deeply political phenomenon that may gain in importance in the upcoming decades and shape part of the relationship between the people of two or many continents. ${ }^{7}$ How then do we restructure the relationship between former colonizing and colonized countries in a postcolonial world of the 21 st century and beyond?

\section{Mainstreaming the Discourse in African History, Archaeology and Heritage Studies}

Mainstreaming the restitution and repatriation debates in historical and heritage scholarship and student training is becoming a necessity in making the discourse non elitist and encompassing. In ensuring that academics teach innovative interdisciplinary research methods in historical and heritage analysis, the integration of practical and theoretical dimensions of object-oriented research must be a central subject of inquiry. This approach can help young scholars to engage with theoretical questions directly by using objects and sources rather than just privileging text. African history used to be written from the perspective of the colonizers and western scholars who privileged the achievements of whiteness by eclipsing the agency of blackness. Pan African writers, among many other scholars, have largely critiqued most of these early stereotypical writings. In contemporary times, well-written critical histories by African and European scholars have deemed it fit to right the wrongs of the misrepresentations of the African past.

However, what is yet to be achieved is the critical analysis of the texts of early European agents who documented the way they looted, acquired or collected African objects from the colonies or from their African areas of operation (Baumann, 2013:71). When these texts are taken on face value in provenance research, they have the potency of glossing over the self-centeredness and biased perspectives of some of these accounts (Leijten, 2015). Most of which may be used by museum gatekeepers to justify the retention of these African objects in European museums. Besides the conduct of critical reviews of such historical documents associated with acquired and looted African objects, the fundamental terms of reference under these restitution discourses and practices should also border on the following: a) the role of African archaeology, and b) contextual issues as well as provenance research now and beyond. Although some African scholars are not in favour of advocating for a universal heritage or a universal museum (see Abungu 2008a), invariably, provenance research would have to redefine what is "shared" or "universal" heritage, as well as give voice to African experts and local owners.

African Archaeology. With its unique methodological ability to stratigraphically unearth sites of human activity through scientific excavations and being able to reconstruct past information through the analysis and dating of past human and material remains, archaeology can contribute to provenance search processes (Apoh 2010, Ashmore and Sharer 2006, Connah 1987, Fagan 1988). Unfortunately, in contrast to the discipline of history, the role of archaeology has so far been mostly silenced in the restitution process and on the issues of provenance studies. It is only through the inspiration and curiosity of a few African archaeologists

\footnotetext{
European colonial expansion led to looting of art objects all around the world, but partly in different time periods or under different conditions. Some of the sketched problems with respect to Africa within this contribution may affect other world regions in a similar fashion, but we do not claim expertise here.
} 
that the role of archaeology has been factored into the restitution debate as an important provenance method in recent time (Apoh 2019). Privileging the use of the methods and discourse of African archaeology can expose the materiality of an oppressive presence of the colonial state that enabled the looting of such objects. It is also capable of identifying and interpreting the objects that were locally produced, exported and imported in the archaeological and ethnographic records and contexts. Fundamentally, an archaeological excavation of all the collections in the storage of European museums must be carried out. This is essential as more often than not, museum management and curators do not know the total number, type and nature of objects and their origins in their storage.

A recent interaction with the curators of the Grassi Museum in Leipzig, Germany revealed that only about 3\% of their total collections are exhibited in their large exhibition halls (S. Bach, personal communication, July 20, 2019). This implies that about $97 \%$ of the objects are in storage, with no proper plan for their exhibition and exposure. African societies and descendants of individuals whose looted property are now stored in foreign museums, stand a limited chance to even know about their existence. In contrast to France, the exact number and nature of collections in German museums is frequently unknown. The report by Felwine Sarr and Benedicte Savoy (2018) and their recent call to 'open the inventories' which has been endorsed by many critical scholars around the globe (see footnote 18 below), provides a clarion call for all museums to push for the full disclosure of African objects in their museum storages. This also lends credence to the need for systematic archaeological excavations to be conducted at places with vestiges of slavery and colonial remains (Apoh, 2013) so as to enrich our understanding of such contexts viz a viz the restitution debate.

Contextual Issues: The insights that archaeology can provide on the debates associated with the provenance of colonial objects in European museums can broaden contextual understandings that can add value to the materials in question and the sites of source regions. For example, the project on the archaeology of German colonialism and missionization, with support from the Volkswagen Humanities Senior Postdoctoral funds, has led to the filling of gaps and the attention to silences associated with German colonialism in Togoland beyond oral accounts and archival texts (Apoh, 2016a, 2016b, 2019). Archaeology therefore can be useful in influencing policy decisions on this discourse. Thus, what we learn from archaeology about shared heritage of colonialism and the built environment at the mission sites as well as the traces of German colonialism in Togoland do reveal the contextual histories of atrocities of missionaries and colonial authorities. In dealing with these issues beyond the museum, such revelations through archaeology and the excavated materials from extant colonial administrative sites could be developed into meaningful and interactive art museums as well as sites of memory, healing and reflections. ${ }^{8}$

Contextual information regarding the histories of source regions and the significance of their material cultural traditions are meaningful as most objects found in European museums are not just isolated remains. These materials could have been part of a cultural collective of a community. Similarly, they could have been part of symbolic and performance cultures that were actively used in shrines,

8 https://www.theartnewspaper.com/news/togo-opens-arts-centre-in-former-colonial-palace (accessed 4 February 2019). 
palaces or households before being taken and exported. This calls for a deeper search and understanding of the use and significance of similar objects, if any, in the source regions that could provide excellent contextual information on them (see Lamptey and Apoh, this volume).

In most cases, sacred African objects commissioned and made in the past were done for specific reasons and within a context of use and application as well as within compelling varied historical moments. Their seizure, theft or collection often destroy and transform their associated practices. If such objects are limited in number, memories about their usage also gets obliterated through time when they are no longer used in rituals, ceremonies and community performances. For example, Kpando oral accounts, which have been documented in local and scholarly sources, do lend credence to the looting of some royal objects in the Kpando palace in 1913 by German colonial forces led by Dr Hans Gruner. The objects were important nodes in relationships between the people of Kpando and neighboring polities before the advent of German colonial rule (Apoh, 2013; also see Hoebuadzu and Opeku, this volume). Two of them appear to incorporate human remains from groups defeated in war by the people of Kpando. While it is disputed how the objects came to Berlin during the colonial era, the existing knowledge already permits to sketch part of the painful issues surrounding the objects appropriated or misappropriated in known colonial contexts.

Provenance Research Now and Beyond. Let us recall that French President Emmanuel Macron promised in his speech in Ouagadougou, Burkina Faso, to return African objects in French museums to their respective countries, so that African youths can have access to their heritage just as the French youths do. This was followed by the much cited report by Felwine Sarr and Bénédicte Savoy. This report has provided an impetus to the call, request and demands for restitution from various quarters within the African continent. Official response to such requests, especially in Germany, has resulted in the establishment of provenance research practices as part of the return process. Much has been discussed and decided on the issue in Germany in the last couple of years with one of the noteworthy developments being the expansion of the focus of the "German Lost Art Foundation", which supports German museums and collections in their much-neglected and underfunded provenance research, beyond the restitution of Jewish art objects looted during the Nazi regime. The public discussion in Germany on issues of restitution has been crystallised around the establishment of the new "Humboldt Forum" in Berlin which was set up to serve as main exhibition platform for the collections of the "Ethnologisches Museum" in Berlin (see infra). 9 The German museum scene is in ebullition due to pressure from the federal government, civil societies and diaspora activism with all asking for the speeding up of the restitution acts. They at the same time also broadly support requests to open the museum inventories on African art objects ${ }^{10}$ and new funding opportunities. ${ }^{11}$ The German government has

\footnotetext{
${ }^{9}$ The Keynote address on the aforementioned MIASA workshop was given by Andreas Eckert who summed up recent events in Germany which have in the meantime gained even further prominence.

${ }^{10}$ https://oeffnetdieinventare.com/ (accessed 4 February 2020), including English and French translations.

11 In January 2019 the 'German Lost Art Foundation' set out criteria for the provision of funding for provenance research projects focusing on collections from colonial contexts and for basic research in this field.
} 
in turn taken a progressive and pro-active stance, ${ }^{12}$ through the establishment of a 'German Contact Point for Collections from Colonial Contexts' at the level of the Cultural Foundation of the German Federal States, where interested parties can launch requests to find missing objects looted during colonial times; commencing operation from 2020. ${ }^{13}$ At the same time, some museums today find it hard to fundamentally question their identity, audience and overall societal meaning.

Deepening the exchange with collections and museums in Africa is therefore high on the agenda. ${ }^{14}$ This fundamentally demonstrates the importance of provenance research and additional sources of funding for the same. Such provenance research requires the establishment of the true owners and origin of the objects in question. It should also establish the mode of collection and acquisition and how it came into the museums and private collections in Europe or destinations outside the source areas. Such a method and practice of digging into the archive and libraries require staking out current theoretical and practical dimensions of interdisciplinary and joint research. The interdisciplinary and intercultural dimension of research concerning contested objects provides the needed foundation for the findings to be obtained in an empirical way. ${ }^{15}$

Provenance research for objects from Africa, particularly those acquired during the colonial era, is therefore necessarily an interdisciplinary and intercultural undertaking. Unlike the narrow goals of research into the provenance of artworks during the Nazi period, developing an understanding of the social life of objects from outside Europe demands the use of the methods and insights of history and allied disciplines. ${ }^{16}$ Nevertheless, how interdisciplinary and intercultural insights and methodologies can best be used to understand the colonial past and the objects entangled in it remains an open and pressing question.

Provenance research is needed to understand the contextual life of acquired, looted or purchased objects. Let us however keep in mind that some African colleagues question the strong emphasis on provenance research, at least when exclusively done by European specialists, arguing that further research could be

12 See framework paper https://www.kmk.org/fileadmin/pdf/PresseUndAktuelles/2019/ 2019-03-25 Erste-Eckpunkte-Sammlungsgut-koloniale-Kontexte final.pdf (accessed 4 February 2020) and Kwame Opoku's views on this https://www.modernghana.com/news/877150/germany-issues-english-versionof-guidelines-on-dealing-with.html (accessed 4 February 2020).

13 http://www.kulturstiftung.de/german-contact-point-for-collections-from-colonial-contexts/ (accessed 4 February 2020).

14 The Goethe Institute ran a series of workshops on the matter, see https://www.goethe.de/de/uun/prs/ med/21644788.html (accessed 4 February 2020).

${ }^{15}$ The Volkswagen foundation and the Gerda Henkel foundation currently fund numerous and promising projects of provenance research, e.g. in cooperation with Namibian and Tanzanian counterparts, see https://www.gerda-henkel-stiftung.de/pressemitteilung namibia; (accessed on 4 February 2020); https://www.volkswagenstiftung.de/aktuelles-presse/geschichten-aus-der-foerderung/die-eigenesammlungsgeschichte-erschlie\%C3\%9Fen-provenienzforschung-im-\%C3\%BCbersee-museumbremen (accessed on 4 February 2020). Whether all salient aspects are taken up in such projects might be questioned. As one African saying goes, whoever has the drum controls the tune. So it is important that funding would not exclusively come from the Global North.

${ }^{16}$ The German discussion is heavily influenced by restitution issues in the context of illegal appropriations before and during World War II. The 'German Lost Art Foundation' has its origins there. The 'Lost Art Database' documents cultural assets which were relocated as a result of the events of World War II, or - in the case of Jewish ownership - items that were illegally confiscated by the Nazis under threat of persecution. One could easily imagine similar initiatives for the colonial context. 
a pretext for not returning these objects. ${ }^{17}$ We do not hold that this would be the outcome in all cases. However, the research process must be collaborative, and it must include scholars or local custodians of cultural knowledge in addition to the use of methods and insights of history, cultural and physical anthropology, archaeology, philosophy, art history, and museum studies. For example, the stolen, looted and/or illegally acquired artefacts of the Royal family of Kpando in the Ethnologisches Museum (in Berlin) is one of such claims that can be subjected to provenance research. Justifiably at the end of such a research, it would be obvious that the objects were indeed looted; this being given prominence in the oral accounts of the people of Kpando.

Redefining Shared or Universal Heritage in Restitution Issues: Cultural objects that are under such restitution demands are not limited to only African objects or objects made by Africans or objects originating from African countries. There are inter and intra-European as well as Euro-Asian and EuroAmerican demands. However, the restitution of looted art from Africa sent or sold to European museums by agents of European colonizing missions is at the centre stage of the debate that is still not geared towards practical solution (Abungu 2008b) and thus needs to be interrogated to garner frameworks for resolution. Engaging in constructive talks about returning objects is an arduous task with varied hydra-headed political, legal, ethical, economic, socio-cultural and human rights ramifications. Two critical issues that are usually contested are the issue of shared heritage and universal heritage. Some proponents and advocates of no-restitution often advance the view that some objects constitute shared heritage, since they have multiple creators and owners, in that they can be kept in Europe and enjoyed by all humanity. This reasoning also foregrounds the idea of universalizing heritage claims.

Request for the return of such objects from state and private museums in Europe are, time and again, rebuffed with paternalist, imperialist, self-centred and racialized statements such as 'the treasures are better protected in Europe'; 'the treasures are seen by more persons in Europe than if they were to be returned to Africa'; 'scholars still need to work on them'; 'manuscripts are too old to travel' ; 'African museums do not have the security and environmental conditions that European museums have'; 'legal difficulties around deaccessioning' ; and many more. These reasons are the stumbling blocks to requests. They are also invoked to create processual stalemates and promote the continuing bid of European museums to erase and deny African agency. Such essentialist positions could be countered with varied points. These include the fact that the "African owners were looted by Europeans in the first place,' 'African art objects have been spoiled and poisoned in European depots,' 'returned objects are not in the same condition as when they were looted', and also 'European ethnographic museums had their high time in the colonial period, but this time has gone' and 'it is time for African scholars and community museums to acquire and work on them now' (Opoku, 2020)"

Admittedly, some objects and legacies of the past are indeed shared heritage. For example, the shared tangible heritage sites, such as the former built German colonial stations and districts in Togoland (namely, Misahöhe, Kpando Todzi, Kete Hedgiswart, Ho Todzi) do attest to this. The ex-colonial buildings and archaeological

\footnotetext{
${ }^{17}$ This was one of the suspicions voiced during the aforementioned workshop.
} 
remains from the listed sites could be considered as shared since they were collectively produced even if at times under duress or forcefully. In the same way, they can collectively be conserved as memory sites and sites of collaborative research and cultural exchange/villages to promote heritage education.

Similarly, some objects from diverse African societies entered into various museums on the African continent without particular care. Such objects were often acquired under questionable circumstances by French and British colonial officers, especially, from one African country and lodged in the museum of other African countries during the colonial periods. The question is: can such objects be considered as shared heritage? Notably, hominid finds and stone tools from excavations by the Leakey family in Tanzania, including from Olduvai Gorge during the colonial period, all ended at the National Museum in Kenya. Long after independence, the two national museums, in Kenya and Tanzania, were able to negotiate their repatriation to their home country in Tanzania ${ }^{18}$. This may also be the case with French-speaking West Africa where huge collections ended up in Senegal from other countries and are still there as that was the "capital" of French West Africa. We are of the view that museums in Africa, especially those in Senegal, must also reveal or declare all foreign objects in their collections that were acquired dubiously or have been tagged as looted. Such a full disclosure can create universal standards to enable societies that may be at loss about the existence of such objects to lay claim to them through a well-defined restitution process. African people's human rights and direct access to looted creative and spiritual works of their ancestors, beg for continuous scholarly debates on these issues on the African continent by both African and international professionals and stakeholders.

Giving Voice to African Experts and Local Custodians: It has been critiqued that most of the debates being held on the issue of restitution and return are elitist, hyper-scholarly and expose a Metropolitan European bias. The marginalization or the silencing of the perspectives of African experts within the public debate and within the practice of restitution has been critiqued at many fora. Similarly, the lack of attention to the voices of the African subaltern and the recipient communities have not been thoroughly mapped out. African and European scholars, museum practitioners, heritage custodians and policy makers seem to be falling short in sustaining the partnerships and collaborative engagements. Such interactions often help to map out best options and practices that will inure to our collective benefits and give closure to affected communities. The respective claims being made by African societies and why it is important to Africanise the debate in this sense is another aspect of the discourse that is being debated. We are at a crossroad: either the debate is pursued in isolation with its risks of further polarisation or we begin to listen to each other.

\footnotetext{
18 Kenya returns fossils to Tanzania. https://www.wantedinafrica.com/news/kenya-returns-fossils-totanzania.html. (accessed 4 February 2020).
} 


\section{Conclusion}

In spurring international interdisciplinary collaboration in restitution and repatriation debates, the provision of frameworks for future research involving different areas of Africa and different object-centered inquiries is a good starting point for collaborations. Such projects, whether focused on collaboration with institutions and scholars or not, must begin with their mainstreaming in academic and nonacademic fora as a way of strategically dealing with such fallouts from the past. Addressing critical questions concerning the use of methods and insights across disciplines therefore is of crucial importance for provenance research and beyond. To what extent do we include provenance research on objects in our curricula in political science, history, art history, heritage studies, and archaeology? We need to foreground object-oriented research and interpret the context of objects themselves using various interdisciplinary and intercultural sources as a way of understanding issues of restitution and repatriation of cultural objects and human remains. But there are also more practical questions: What is the state of museums in Africa? What role do they play in society? Could African museums take advantage of the momentum of the described debate? What is the political agenda in various African states on the issue of looted objects? Why did politicians (and part of the public) in Europe got suddenly interested (again) in the question of colonial objects? 


\section{References}

Abungu, G. (2008). Archéologie, pillage et restitution : La destruction du futur de I' humanité. In J. P. Demoule and B. Stiegler (Eds.), L'Avenir du Passé: Modernité de I'Archéologie. (pp. 154-70). Paris: Editions la Découverte.

Abungu, G. (2008). Universal Museums: New Contestations, New Controversies. In M. Gabriel and J. Dahl (Eds.), UTIMUT: Past Heritage-Future Partnerships, (pp. 32-43). Copenhagen: IWGIA/NKA

Apoh, W. (2019). Revelations of Domination and Resilience: Discovering the Buried Past of the Akpinis, Akans, Germans and British at Kpando, Ghana. Accra: Sub-Saharan Publishers

Apoh, W. (2016). Ruins, Relics and Research: Lasting Evidence and Perceptible Consequences of the Prussian and German Colonial Past in Ghana. Deutscher Kolonialismus: Fragmente seiner Geschichte und Gegenwart. German Historical Museum. Special Exhibition on German Colonialism. Berlin: Theiss. 92-99.

Apoh, W. (2016). Ein Postkolonialer Blick. Die Deutsche Präsenz im Westlichen Togo zwischen 1884 und 1914. In Alexis von Poser \& B. Baumann (Eds), Heikles Erbe. Koloniale Spuren bis in die Gegenwart (pp 174-183). Dresden: Sandstein Verlag. (Hannover State Museum Special Exhibition Catalogue).

Apoh. W. (2013). The Archaeology of German and British Colonial Entanglements in Kpando-Ghana. International Journal of Historical Archaeology, 17 (2), $351-375$

Apoh. W. (2010). Concise Anthropology. The Five-Field Approach. Iowa. Kendal Hunt Publishers.

Apoh. W \& Mehler. A. (2019) Restitution of Art Objects: Bringing in African Perspectives, in: TRAFO - Blog for Transregional Research, 06.02.2019, https://trafo.hypotheses.org/1781 (accessed on 4 February 2020)

Ashmore, W and Sharer, R. (2006). Discovering Our Past: A Brief Introduction to Archaeology. 4th Edition. McGraw Hill.

Baumann, D. (2013). Exkurs: Der Togoforscher Ernst Richard Reinhold Baumann (1871-1895). In Runge, J. Republik Togo. Geographische Einblicke zwischen dem Golf von Guinea und der Sudanzone in Westafrika. Aachen: Shaker Verlag

Connah, G. (1987). African Civilizations: Precolonial Cities and States in Tropical Africa: an archaeological perspective. Cambridge: Cambridge University Press.

Fagan, B.M. (1988). Archaeology - A Brief Introduction. Colchester:Scott Robin. 
Garsha, J. (2019). Expanding Vergangenheitsbewältigung? German Repatriation of Colonial Artefacts and Human Remains. Journal of Genocide Research 1-16.

Hersak, D. (2019). Restitution: Debate and Action, African Arts. 52 (1): 8-10.

Koessler, R. (2019). The Bible and the Whip -Entanglements surrounding the restitution of looted heirlooms, ABI Working Paper; 12, Freiburg i. Br.

Leijten, M. H. (2015). From Idol to Art: African 'Objects with power': A Challenge for Missionaries, Anthropologists and Museum Curators. Leiden: African Studies Centre

M'Bow, A-M. (2009). A Plea for the Return of an Irreplaceable Cultural Heritage to Those Who Created It'. In Lyndel V. Prott (Ed.) Witnesses to HistoryDocuments and Writings on the return of Cultural Property, ( $\mathrm{p} \mathrm{30)}$ UNESCO Publishing.

Murphy, M. and Tillier, B. (2019). Éthique et politique de la restitution des biens culturels à l' Afrique: les enjeux d'une polémique. Sociétés \& Représentations 2, 257-270.

Nkrumah, K. (1962) Towards Colonial Freedom. London: Heinemann.

Opoku, K. Some Have Waited for 100 Years; Others Are Tired After Few Months: Time In Restitution Matters. https://www.modernghana.com/ news $/ 968851 /$ some-have-waited-for-100-years-others-are-tired.html . (accessed 4 February 2020)

Sarr, F. \& Savoy B. (2018). The Restitution of African Cultural Heritage. Toward a New Relational Ethics. Paris: French Ministry of Culture.

Thiemeyer, T. (2019). Restitution als Symbolischer Akt. Zeitschrift für Volkskunde 115 (2): $260-368$.

Van Beurden, S. (2015) Authentically African: Arts and the Transnational Politics of Congolese Culture. Athens, $\mathrm{OH}$ : Ohio University Press.

Van Dantzig, A. (1980) Forts and Castles of Ghana. Accra, Ghana: Sedco Publishing. 